\title{
Towards an orientation of higher education in the post Rio+20 process: How is the game changing?
}

\author{
A. Beynaghi a,b,c,*, F. Moztarzadeh a,b,c, R. Maknoon ${ }^{\mathrm{a}, \mathrm{b}, \mathrm{c}}$, T. Waas ${ }^{\mathrm{d}}$, M. Mozafari \\ e, J. Huge' d,f, W. Leal Filho ${ }^{\mathrm{g}, * *}$ \\ Technology Foresight Group, Department of Management, Science and Technology, Amirkabir University of Technology, Tehran, Iran b Office of \\ Sustainability, Amirkabir University of Technology, Tehran, Iran \\ Futures Studies Research Institute, Amirkabir University of Technology, Tehran, Iran d Centre \\ for Sustainable Development, Ghent University, Ghent, Belgium \\ Nanotechnology and Advanced Materials Department, Materials and Energy Research Center (MERC), Tehran, Iran ${ }^{\mathrm{f}}$ Systems \\ Ecology \& Resource Management Lab, Universite' libre de Bruxelles, Brussels, Belgium \\ $\mathrm{g}$ Hamburg University of Applied Sciences, Faculty of Life Sciences, Hamburg, Germany
}

A B S T R A C T

The purpose of this paper is to identify and assess the implications of sustainable development for the future orientation of higher education, especially after the 2012 United Nations Conference on Sustainable Development $($ Rio +20$)$. A qualitative trend analysis is

Keywords: being used for this purpose, in the context of which three macro trends are combined: (1) Higher education higher education that has been developed via five periods; (2) sustainable development that has evolved through three stages; and (3) the nexus between sustainable development and Rio +20 higher education which has strengthened has evolved through three stages; and for the

Future the macro trends regarding their possible interactive effects (through an expert panel.

Sustainable university discussion) demonstrates that higher education and universities under the influence of sustainable development elements are entering into a new era in which the function of "higher education for sustainable development" could be interpreted as the seeds of a newly emerging mission for universities. In this regard, it is expected that the concept of "sustainable university" is likely to become more common to meet the emerging mission. Consistent with the Rio +20 outcomes, the authors analyzed the concept of "sustainable university" and identified the fact that it is practically divided into three interrelated and complementary categories, namely social-, environmental-, and economic-oriented university in pursuit of actualizing sustainable development.

\section{Introduction}

Higher education (HE) plays a crucial role in fostering the adaptation and re-invention of society in times of global changeability to compete and survive (Weisbrod, Ballou, \& Asch, 2008; Zakaria, 2008). The power in HE might well influence

on the political power balance around the world (Ritzen, 2006). For example, Zakaria suggested, in his book entitled "The Post American World", that the world is facing a change in the structure of political power and that HE is an opportunity for guaranteeing the current status of the United States as a global leader (Zakaria, 2008). Indeed, the HE sector in industrialized nations such as the United States is comparable to many important sectors of the economy, since it has a turn-over in excess of US\$ 21 billion per year. According to the statistics, HE is the area in which the United States has been performing especially well (Zakaria, 2008). In Australia HE is ranked among the top three or four of the country's export industries (Devos, 2003; Stoddart, 2012). Therefore, a large number of countries, particularly the developed ones, develop and adjust their macro policies in order to improve and reinforce their HE systems. As further examples, one can consider the experiences from the United States, the United Kingdom and Australia, that have been recently able to intelligently attract international students (Ritzen, 2006). This indicates how these nations have been successfully operating on the basis of the future studies to explore the opportunities relied on which they have made their policies. Thus, tending to hold remarkable global positions in the future, both developed and developing countries are obliged to turn HE into one of the most effective sectors to be invested in. But it is clear that successful investment, accurate policy making, and proper planning in this field are related to a better understanding as well as identification of the future outlook of $\mathrm{HE}$ and a precise observation of the upcoming potential opportunities and treats. Therefore, it could be claimed that the present competitive world calls for a precise identification of the future orientation of HE.

In this regard, many researchers and experts have recently adopted different approaches toward the evaluation of the future orientation of $\mathrm{HE}$ and particularly universities. If one uses a methodological standpoint, many studies conducted in this sector follow into three main categories:

First category: The basic changes in university structures.

In this category, the focus is on the internal changes of universities, and what may be needed to improve their structures in the future (like the ones in the infrastructures, missions, organizational values, management, funding sources, planning, etc.). For instance, Hashimshony and Haina (2006) have analyzed the effect of social, cultural, economic, and technological changes on the physical structure of universities in the future, and presented three scenarios in this context. Cunha and Putnik (2007) have developed a model for university virtualization with the emphasis on transformation and virtualization of universities confronting the future needs and economic changes. As another example, Hayes (2007) has 
highlighted the importance of marketing in universities with explaining its role in the future. This pointed out that universities need to consider marketing in their strategic planning, so that they could supply the financial sources, attain more appropriate planning, achieve more effective costing, and eventually enhance the competitiveness in the future. This study made efforts to use Delphi method in order to identify the specific role that marketing could possibly play in the organization charts of universities in the future.

Second category: The changing role of universities in society.

Here an emphasis is given to considering the future of $\mathrm{HE}$ and universities, as a critical factor at the local, community and national levels, and their relation with other factors like government, industry, economy, etc. For example, concentrating on the ever-increasing role of universities in knowledge-based societies, Etzkowitz, Webster, Gebhardt, and Terra (2000) have evaluated the inter-relation between universities, government, and industry. They examined the level of cooperation among these three pillars in different countries, and then turned into the necessity of taking a future studies approach along with long-term planning for universities to achieve entrepreneurship. As another example, it is possible to refer to a survey by Azman, Sirat, and Karim (2010) that have been conducted to assess the status and the role of HE (universities in particular) in Malaysia. With regard to the national priorities, this survey designed multiple scenarios for HE and its position in Malaysian future society.

Third category: Trends in HE at the international level.

This category analyze the future of $\mathrm{HE}$ and universities as an effective factor at the international level through assessing the macro processes and key driver forces like globalization, technological progress, demographic changes, and ecological challenges. For instance, Ritzen (2006) has sketched some scenarios for the future of $\mathrm{HE}$ at an international level regarding the global trend of top talent mobility. This study emphasized that $\mathrm{HE}$ is an international organization, and then introduced the attraction of international talent as an important factor to empower scientific and subsequently political capability. Along with the notion that the progress made in Information and Communication Technology (ICT) has opened the gateways of knowledge to everyone, Atkins (2005) asserted that such a progress could make a considerable evolution in the future of HE. In fact, ICT has been assumed as one of the most important infrastructure as well as an effective factor on the future of HE. This study also evaluated the probable challenges under the influence of ICT to sketch the potential border of the HE in the future. Recently, Mellow and Woolis (2010) tried to describe the macro trends and major influences that form the future of HE, and then analyzed a variety of factors which may affect the future of the field. They finally highlighted the impact of three factors, namely globalization, technological advances and the effect of market place on the future of $\mathrm{HE}$.

From another standpoint, recent studies related to the future of HE and universities can be classified in terms of using various future studies tools. Futures studies methods are both prescriptive and descriptive. The former focuses on what the future should be, and leads to a desirable picture of the future (vision), and then asks how to get there (Kreibich, Oertel, \& Wolk, 2011; Wilkinson \& Mangalagiu, 2012). There are some studies that have focused on this approach for the future of HE, relying on backcasting and vision-based methods (Vlasman, Quist, \& Mansvelt, 2004). On the contrary, the latter attempts to objectively describe what the future will be or could be. Many scholars and international organizations have taken descriptive approaches and offered a range of alternative images for this field, using scenario-based (Barth et al., 2011; Blass, Jasman, \& Shelley, 2010; Ritzen, 2006; Vincent-Lancrin, 2004), Delphi-based (Hayes, 2007; Huisman, de Boer, \& Bo'tas, 2012), and trend-based methods (Boer et al., 2002). Among all these methods, trend analysis is one of the most powerful tools for exploring future developments (Liebl \& Schwarz, 2010; Saritas \& Smith, 2011). According to van der Heijden (2004), a trend is a pattern that one reads in a series of events. Moreover, Atilla Oner, Basoglu, and Kok (2007) point out that trend analysis monitors changes in chosen variables from the past into the present, focusing on the cumulative tendency of the change in any specified period of time generated by unique events. In fact, trend analysis aims to observe and register the past performance of a certain factor, and project it into the future (Saritas \& Smith, 2011). It involves analysis of two groups of trends: quantitative that is mainly defined in the context of statistics (particularly in time-series analysis), and qualitative that is used to develop concepts and theories that are crucial for social, organizational and political patterns (Atilla Oner et al., 2007). Most of the existing methods for qualitative trend analysis are based on discriminative models. Although one of the disadvantages of such models is that many heuristic rules or local search methods are needed (Villez \& Rengaswamy, 2013), they help us to effectively understand the social world. In this regard, several trends can be combined to picture a possible future for a sector of interest, such as HE. Different macro trends, such as technology, aging population, globalization, economics, culture, politics, etc. could impact on the future orientation of HE (Duderstadt, 2012). This research aims to specifically explore the implications of sustainable development (SD) as a significant global trend (DiSano, 1999) for the future orientation of HE.

Taking into account qualitative trend analysis as a general method, this analysis is conducted in three steps to identify directions of changes separately for the qualitative variables ${ }^{1}$ (HE, SD, and the nexus between SD and HE (SD-HE)) over time: (1) identifying several distinguished and significant events, such as international conferences, published declarations, books, papers, etc. related to each variable through reviewing the literature, (2) conducting a document analysis (Bowen, 2009), including the outcome documents of these events, and (3) integration and analysis of characteristics derived from the two previous steps.

This paper is divided into the following sections. Analysis of the trend of HE to provide an underpinning understanding of how HE has been changed during the recent decades (Section 2). Taking a deep look at the trend of SD focuses on how this trend has been evolved (Section 3). The simultaneous analysis of the mentioned trends demonstrates that a nexus between SD and HE (SD-HE) have been created as another global trend (Leal Filho, \& Manolas, 2012) (Section 4). Considering the 2012 United Nations Conference on Sustainable Development (Rio + 20) as a significant event, this paper tries to investigate the status of these three trends. The paper seeks to identify the future orientation of HE with regard to the possible interactive effects of these trends after Rio +20 (Section 5). For this purpose, an expert panel discussion was conducted at the "Sustainability and Higher Education Conference" by "Futures Studies Research Institute" and "Office of Sustainability" at AmirKabir University of Technology (AUT) in Tehran in December 2012. A multi-disciplinary team came from different backgrounds (one from futures studies, one from science and technology policy, one from SD and environmental management, one from HE development planning, one from HE policy, and one from strategic management of science and technology). Although each team member had different backgrounds, they were working 
within the HE sector and they were quite familiar with this field. Finally, the results have been extracted from a collaborative working and panel discussion entitled "the future of higher education in the aftermath of Rio $+20^{\circ 0}$.

2. The general trend of $\mathrm{HE}$

To fully understand the future changes and orientations of HE, it is very useful to initially investigate the long-term fundamental changes that historically have taken place in this field. The classification used bellow is meant to provide a rough overview on the fundamental changes that HE has experienced through different periods. Considering universities as the major representative of HE, this periods could be classified as follows.

\subsection{Elite universities (up to the second half of the 20th century)}

In this period, elite universities consisted of a limited number of students, mostly men and from the higher levels of the society. In the early 19th century, elite universities were mostly serving religious organizations but from the late 19th and early 20th centuries they started serving other sectors of society. In this age, the focal problem for universities was to have academic independence and freely follow their traditional missions (Greenwood, 1995).

2.2. Universities and the social massive demands (since the 1950s)

After World War II, because of the revolution in the population and increasing the literacy and pre university education on the one hand, and increasing the trend of societal democratization on the other, higher education was considered as a citizenship right with the aim of providing equal opportunities for all the groups of society to obtain tertiary education. In this way, the universities faced increasing social demands. Most families considered higher education as a ticket for a better life and social mobility (Volkwein, 1999). What made universities to grant that overwhelming social demand for sure was assurance and support of mostly public funding resources (Peterson, 1999).

52

\subsection{Universities and social movements (since the 1960s)}

In this period, a social movement happened focusing on civil rights, women rights, ethnics and minorities and the Vietnam War had a great influence on these movements. Many universities faced a crisis of reputation and legitimacy. They were expected to play an effective role in social and political criticism and defend the rights of minority groups, women and social movements. In this situation, many university campuses faced regulation problems (Peterson, 1999). Therefore, "Student Development Theories" ${ }^{2}$ were stimulated a lot of debate among authorities (Knight, Moore, \& Coperthwaite, 1999). 2.4. Universities and the market, industry and business demands (since the 1970s)

In the 1970s, various economic crises and market instability led to a new focus on productivity and efficiency. Financial constraints changed the way of thinking and there was a realization that universities' graduates, with the right skills and knowledge could be very useful to the productivity and efficiency for industries (Peterson, 1999). After the 1980s, the level of direct financial support from governments to HE had a decrease, partly due to reductions in tax revenues and increasing competition among universities. A number of grants were turned into loans and also budgets into projects, and universities had to be ready for accountability to the market and business for securing some parts of their financial needs from external sources (Dionne \& Kean, 1997). In this period, the problem of evaluation and measurement of university teaching and research, and planning and policy analysis of HE became even more important (Peterson, 1999).

2.5. Universities and post-industrial evolution along with the information society (since 1990s)

From 1990s and the starting of the 21st century, electronic revolution and information age and appearance of the net society, virtual organizations and changes in societal conditions, forced universities into a new experience in which they encountered a revolutionized academic environment, with a wide diversity, complexity and competitiveness, in a global scale (Cutright, 2001). Dimensions of these challenges were entirely different in nature and quality from what universities were facing in prior periods. In this period, many universities changed or adapted their structures and role (Farasatkhah, 2009; Peterson, 1999).

In each period, universities have faced different issues and consequently taken various orientations, which have been well-depicted in their visions, missions, strategies and plans. In fact, HE could be historically introduced as a system which has been always influenced by the fundamental changes owing to the long-term environmental factors, and then constantly has adapted to the environmental and social demands. Therefore, HE could be considered as an adaptive system. Fig. 1 briefly introduces each of these five periods with their issues and main emphasis.

An analysis of this trend shows that the long-term goal of HE and universities is not only about the advancement of science just for science's sake. Rather, "advancing science, serving society" ${ }^{3}$ is the ultimate goal as a desire improvement in all aspects of life. This mission necessarily entails enough attention to the principle needs of societies. 


\section{The trend of SD}

The question of how the trend of SD has evolved over the past decades, has become a controversial issue of debate among scholars. Since the concept of SD is very broad, different experts may give various types of responses to this question based upon their expertise (Du Pisani, 2006; Quental, Lourenc,o, \& da Silva, 2011; Seidel, 2011). Many authorities believe that the theoretical framework for SD has evolved through a series of significant events, such as international conferences and summits, published declarations, books, papers etc. (Drexhage \& Murphy, 2010) (Fig. 2). In this regard, international organizations, especially the United Nations, have played a key role in creating and promoting public awareness, international agreement and effective cooperation toward SD (Lisa, 2007).

Considering SD as an ongoing stream, the first United Nations Conference on the Human Environment (UNCHE) in Stockholm, Sweden

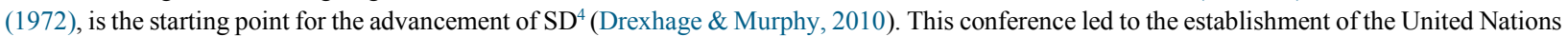
Environment Program (UNEP) in 1974, as well as to the creation of many national environmental protection agencies and international organizations. It has been believed that the recognition to revitalize humanity's connection with nature was one of the important outcomes of this conference (Paul, 2008).

The term of "sustainable development" was popularized in a report published by the World Commission on Environment and Development (WCED) in 1987, "Our Common Future" (Brundtland, 1987). This report defined SD as a development which meets the needs of the present without compromising the ability of future generations to meet their own needs (Drexhage \& Murphy, 2010). This statement emphasizes that the future generations have the same rights to a fulfilled life as today's. 


\section{[(ig._1)TD\$FIG]}

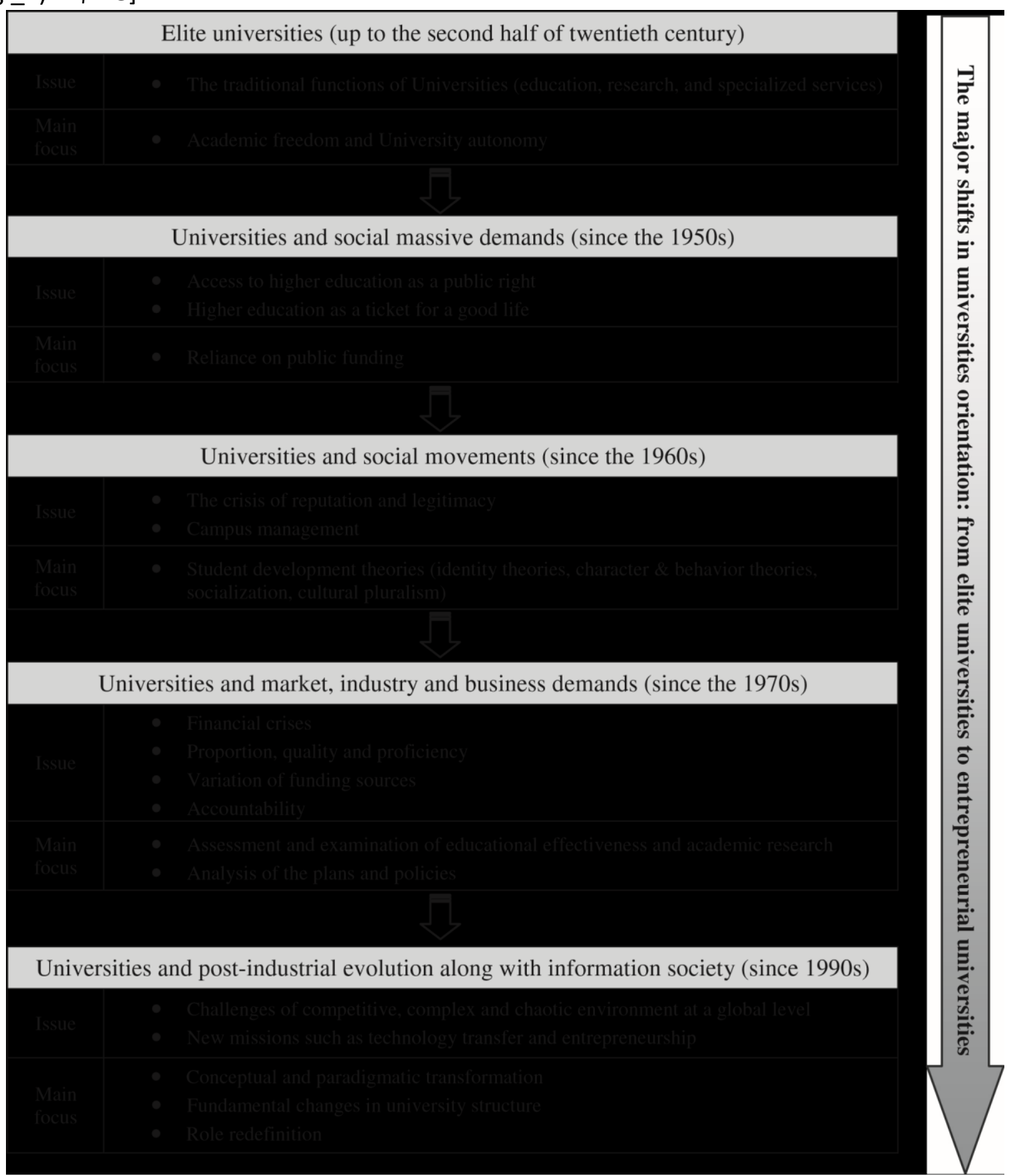

Fig. 1. The trend of HE (Etzkowitz, 2004; Farasatkhah, 2009; Peterson, 1999; Trencher, Yarime, McCormick, Doll, \& Kraines, 2013).

In 1992, more than 100 heads of countries met in Rio de Janeiro, Brazil, for the United Nations Conference on Environment and Development, also called UNCED(UnitedNationsConference, 2013).The meeting adopted among other documents such as the Rio Declaration on Environment and Development and the Biodiversity Convention, an agenda for environment and development in the 21st century, commonly called "Agenda 21"' (http://sustainabledevelopment.un.org/content/documents/ Agenda21.pdf).

In 2002, ten years after the Rio Conference, the World Summit on Sustainable Development (WSSD) was convened in Johannesburg, South Africa, to renew the global commitment to SD (Hens \& Nath, 2003). This conference, under the influence of the Rio objectives, was an effort to find a mutual path to a world with the vision of SD (Koroneos \& Rokos, 2012). 
The ongoing stream of the conferences and summits was followed by Rio +20 in Rio de Janeiro, 2012, when SD reached its peak to catch the global eyes. In fact, forty years after the Stockholm conference, and twenty years after the Rio conference, 


\begin{tabular}{|l|l|}
\hline Limits to growth paper (Meadows, 1972) \\
\hline $\begin{array}{l}\text { Habitat, the UN Conference on Human } \\
\text { Settlements: The First global meeting to link the } \\
\text { environment and human settlement } \\
\text { (http://www.unbrussels.org/agencies/habitat.html) }\end{array}$ \\
\hline $\begin{array}{l}\text { World Conservation strategy: a strategy published } \\
\text { by the International Union for Conservation of Nature } \\
\text { and Natural Resources (IUCN) (www.iucn.org; } \\
\text { IUCN, UNEP, \& WWF, 1980) }\end{array}$ \\
\hline
\end{tabular}

Climate Change: Meeting in Austria of the World Meteorological Society, UNEP and the International Council of Scientific Unions reports on the buildup of carbon dioxide and other "greenhouse gases" in the atmosphere (http://www.wmo.ch)

UN Conference on Environment and Development (UNCED): Agreements are reached on the action plan Agenda 21, the Rio Declaration (United Nations Conference, 2013)

Kyoto Climate change Protocol: At Kyoto, a new set of targets for the reduction of greenhouse gases was agreed

(http://unfccc.int/kyoto_protocol/items/2830.php)

UN Millennium Development Goals: One of the largest gathering of world leaders agrees to a set of time-bound and measurable goals for combating poverty, hunger, disease, illiteracy, environmental degradation and discrimination against women, to be achieved by 2015 (UN, 2010)

Millennium Ecosystem Assessment: 1,300 experts from 95 countries provide scientific information concerning the consequences of ecosystem change for human well-being

(http://www.millenniumassessment.org/en/index.html)

UN Conference on Sustainable Development (Rio+20): Fifty years after Stockholm and twenty years after the Earth Summit, the global community reconvenes in an effort to secure agreement on "greening" world economies through a range of smart measures for clean energy, decent jobs and more sustainable and fair use of resources (The Future We Want, 2012; United Nations Conference, 2012)
The work builds the foundation for the 1987 report,

Our Common Future

(http://www.oecd.org/env/)

International conference on Environment and Economics (OECD): This conference concluded that

1984 environment and economics should be mutually reinforcing (http://www.mofa.go.jp/policy/economy/ summit/2000/past_summit/10/e10_a.html)

Our Common Future (Brundtland Report): A report of the World Commission on Environment and Development, weaves together social, economic, cultural and environmental issues and global solutions. It popularizes the term 'sustainable development' (Brundtland, 1987)

\section{World Summit for Social Development: This} summit expressed a commitment to eradicate poverty (http://www.un.org/esa/socdev/

wssd/text-version/index.html)

Earth Charter: the charter concentrates on fundamental ethical principles for building a just, sustainable and peaceful global society in the $21 \mathrm{st}$ century (http://www.earthcharterinaction.org/content/ pages/Downloads $\% 20$ of $\% 20$ the $\% 20$ Earth $\% 20$ Charter \%20Text; ECI, 2008)

\section{World Summit on Sustainable Development} (WSSD): This conference, under the influence of the Rio objectives, was an effort to find a mutual path to a world with the vision of sustainable development (Hens \& Nath, 2003)

\section{Introducing the concept of "planetary}

boundaries": Scientists introduced this concept in a highly influential article in Nature. The concept quantifies our proximity to limits in nine areas, including biodiversity, chemicals, climate change, oceans acidification, fresh water and others (http://www.stockholmresilience.org/research/ researchnews/tippingtowardstheunknown/ thenineplanetaryboundaries .4.1fe8f33123572b59ab80007039.html) 
Table 1

A new SD framework including 26 thematic areas and cross-cutting issues (The Future We Want, 2012).

\begin{tabular}{ll}
\hline 1. & Poverty eradication \\
2. & Food security and nutrition and sustainable agriculture \\
3. & Water and sanitation \\
4. & Energy \\
5. & Sustainable tourism \\
6. & Sustainable transport \\
7. & Sustainable cities and human Settlements \\
8. & Health and population \\
9. & Promoting full and productive employment, decent work for all and social protection \\
10. & Oceans and seas \\
11. & Small island developing country \\
12. & Least developed countries \\
13. & Landlocked developing countries \\
14. & Africa \\
15. & Regional efforts \\
16. & Disaster risk reduction \\
17. & Climate change \\
18. & Forests \\
19. & Biodiversity \\
20. & Desertification, land degradation and drought \\
21. & Mountains \\
22. & Chemicals and waste \\
23. & Sustainable consumption and production \\
24. & Mining \\
25. & Education \\
26. & Gender equality and the empowerment of women \\
\hline
\end{tabular}

the world community gathered in Rio +20 , in order to evaluate the current status of SD and its progress, and to suggest plans for a more sustainable world. Thus, the title Rio +20 indicates a historic event that reflects twenty years of efforts and progress made to improve the world.

The objective of the conference was to renew political commitments for SD, through the assessment of progresses and gaps in the implementation of decisions made at the major summits, and the discussion of new and emerging challenges (United Nations Conference, 2012). However, Rio +20 tried to define a new vision of development for the future, and published its outcomes as a common denominator, entitled "The Future We Want"' (The Future We Want, 2012) in which governments agreed with the support of 26 thematic areas and cross-cutting issues for a sustainable world (Table 1) (Miyazawa, 2012).

The following results can be inferred from the document analysis of the outcome documents of the mentioned events in Fig. 2:

Paying attention to the "human environment" can be considered as the starting point of the trend. Gradually, in a larger scale, "environment" and its vital role for human life became more and more obvious. In other words, world community became aware of the crucial importance of protecting the earth in order to have a healthy life. By the time, the world community progressively found out that inappropriate patterns of "development" endanger the environment. Hence, simultaneous attention to the "environment and development" has been taken into consideration. The ongoing stream of this trend was followed by the nexus between environment and development that led to the advent of "sustainable development" (Fig. 3).

SD has been gently moving from the margins to the mainstream, so that Rio +20 confirmed that SD has become one of the main global issues.

"The Future We Want", is not just a mere document or statement, but it is the essence of forty-year experience of world community toward achieving SD. In fact, Rio +20 attempted to cover all dimensions of SD in its final outcome document to be able to provide a new vision of development for the future.

\section{The trend of SD-HE}

Since 1972, a nexus between SD and HE trends has been created, so that it gradually led to the formation of a new trend, namely the introduction of SD principles in HE. This nexus has been gradually reinforced by the evolution of SD concept as well as understanding the importance of such approach for the human. Moreover, a positive welcome has taken by HE toward this approach (Wright, 2002). Therefore, this nexus is nowadays considered as a global trend (Leal Filho \& Manolas, 2012).

During the last decades, the formation and reinforcement of the nexus have also encountered a number of challenges and obstacles (Corcoran \& Wals, 2004a). As can be seen in Fig. 4, although the nexus has gradually gained power during the past forty years, there are many universities that have not stepped into this area yet (IAU, 2011). Many efforts have been made by 


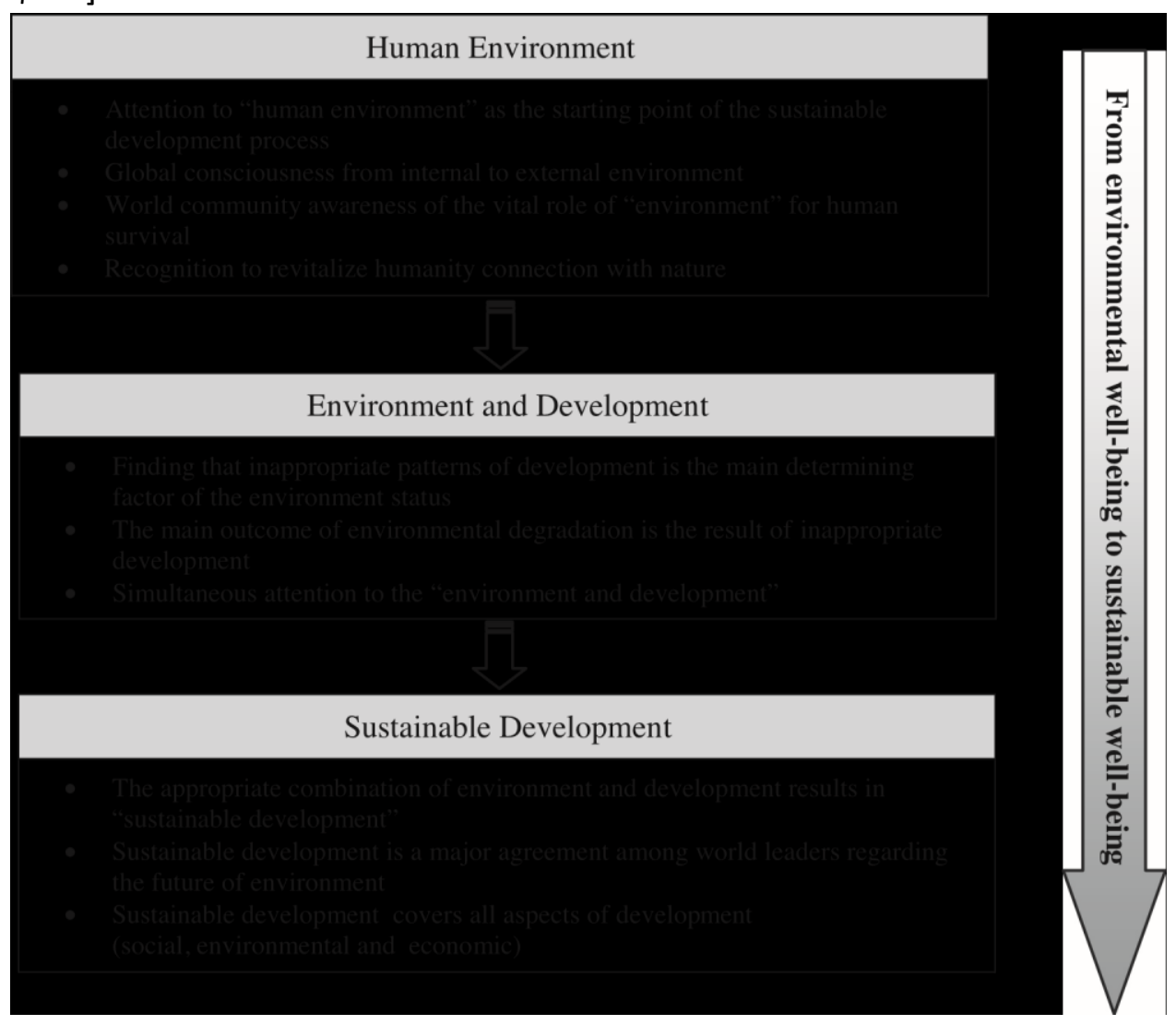

Fig. 3. The trend of SD from 1972 to 2012 .

a large number of researchers and experts to identify and resolve these challenges through various perspectives (Brinkhurst, Rose, Maurice, \& Ackerman, 2011; Clugston \& Calder, 1999; Corcoran \& Wals, 2004b; Leal Filho, 2010a; Lozano, 2006a; Ryan, Tilbury, Corcoran, Abe, \& Nomura, 2010). Although, several - but not all - universities have been able to achieve considerable success, they are not still fully capable for covering all the aspects of SD, the shaded area in Fig. 4.

In this section, after identifying the significant events related to SD-HE, shown in Fig. 5, an exhaustive review of the major events'outcomeshasbeenconducted.Infact,thedocumentanalysisconsistedofanexaminationofleadingSD-HEdeclarations

orcharters.Aframeworkhasbeenrecognizedtoillustratehowthenexushasbeenformedandevolvedonthebasisofapathway followed by successful universities from 1972 to 2012 . This model comprises three dependent phases each one is the prerequisite of the next one. The model, indeed, could be applied by all universities that tend to take the SD approach.

\subsection{The formation mechanism and evolution of the nexus between SD and HE}

\subsubsection{First phase: a new attitude in HE toward SD}

Since the advent of SD trend in 1972, the world attitude gradually changed to the environment (Quental et al., 2011). This has begun appear in the scope of the universities, as the most important section of HE, through developing and expanding the disciplines associated with the environmental congresses, talks, and publications (Wright, 2002). On the other hand, during these years universities have been confronted with market, industry, and business demands (see also Fig. 1) (Farasatkhah, 2009). As a result, universities had no other choices but to seek for technological developments and to supply the marketbased and industrial demands encouraged by environmental factors. However, some universities gradually began to take the new SD approach after 1972, when they planned to host the talks over environment and form a new insight into the concept of development (Wright, 2002). This approach had not been able to integrally operate and influence universities, but it gradually changed the human's look at the world, revived the outdated relations with the surrounding nature, and settled in vision of some universities. Indeed, it could be suggested that SD made different universities to pay more attention to this socalled new born paradigm (Calder \& Clugston, 2003).

\subsubsection{Second phase: sustainability in $\mathrm{HE}$}

After taking a new attitude toward SD by some universities (phase 1), these universities became truly welcome places for SD under the influence of the distinguished SD-HE events. It was not only the beginning of the second phase, but a quantum 
[(ig._4)TD\$FIG]

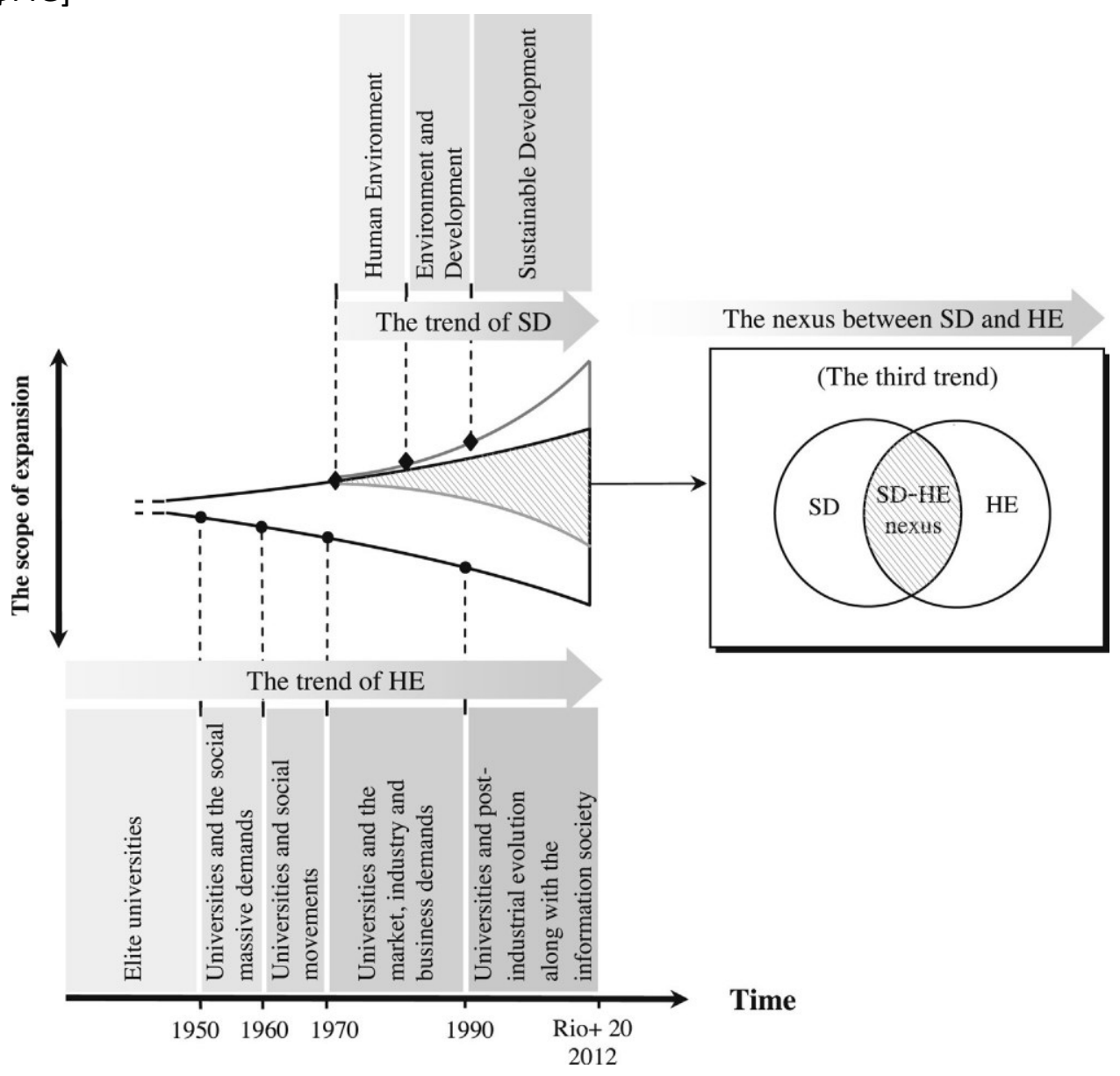

Fig. 4. The formation mechanism and evolution of the nexus between SD and HE from 1972 to 2012.

leap for the relation between SD and HE through different ways including green movements in universities, sustainability in the curriculum, and establishment of offices, centers and departments for SD (Leal Filho, 2010a, 2010b, 2011a). In fact, a great consideration paid to SD by universities during this phase. Although several universities of the advanced nations were the pioneers of that reaction, some universities even in less developed countries were gradually absorbed (IAU, 2011). Therefore, it seems that these series of events and their outcomes were not only routine conferences or statements on SD, but also the harbinger of a new paradigm in which the reflection of SD in HE can be indebted of these events. ${ }^{5}$

\subsubsection{Third phase: HE for SD}

After the awareness of different universities about SD paradigm, and taking a new attitude toward SD (the first phase), and gradually well establishing of this approach (the second phase), it could be now suggested that the relation between SD and HE has entered into a new (third) phase. Universities that have successfully passed the first two phases and stepped into the new one, are taking a new mission for making a sustainable world and playing a leadership role for a sustainable future. In this phase, the universities will shape the basis of the future of SD. In fact, they are one of the most significant driving forces for SD.

To prove such a claim (three mentioned phases), a valid series of universities have been studied to find out their sustainability statuses.

4.2. Methodology

Many scholars have tried to evaluate sustainability status in universities from different points of view (Cole \& Wright, 2005; Lozano, 2006b). However, any ideal method has not been developed yet. This section tries to present an initial 


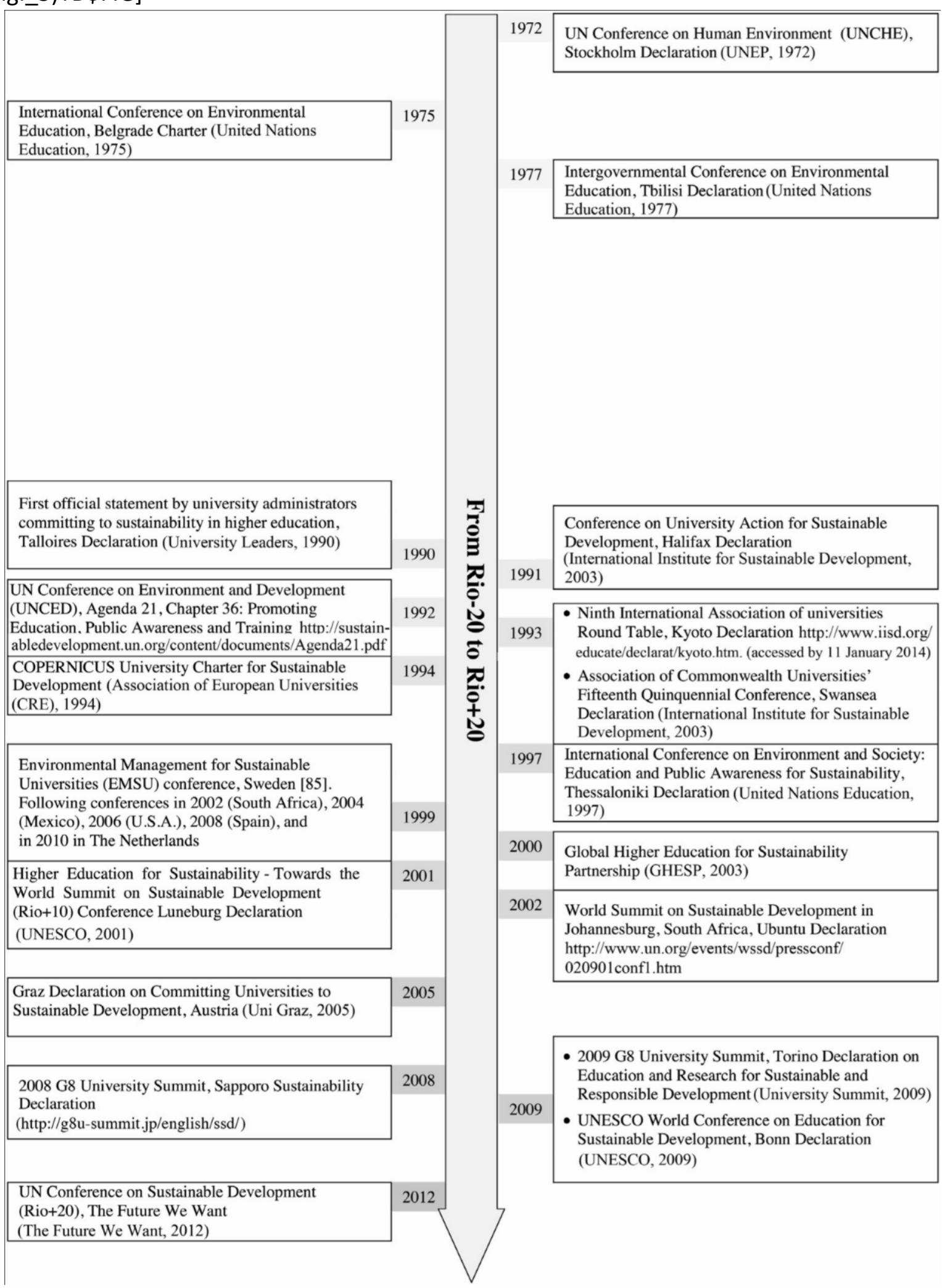

Fig. 5. Selected significant international events that has impacted on the evolution of SD-HE from 1972 to 2012 (Association of European Universities (CRE), 1994; ECI, 2008; EMSU, 1999; GHESP, 2003; International Institute for Sustainable Development, 2003, 2014; UN, 2010; UNESCO, 2001, 2009; Uni Graz, 2005; United Nations Education, 1975, 1977, 1997; University Leaders, 1990; University Summit, 2009). 
description of how sustainability has been institutionalized through evaluating any activities on sustainability at universities. Since some universities have been successfully able to implement SD approach, at first, identifying and analyzing all these universities is required which takes a very difficult procedure. For simplicity, top 20 universities ${ }^{6}$ have been selected as samples. There are two merits of the approach. First, top universities usually enter faster into new fields while other universities are involved with a delay. However, in some cases, other universities could be pioneer. Second, top universities generally provide well-documented reports on the web to support global access to their academic knowledge.

For the purpose, the following parameters have been evaluated:

1. Level of SD activities: to show the level of activities which have done by the universities in the area of SD.

2. Scope of SD activities: to identify the thematic areas that the universities cover by their activities, considering that the paper takes Rio +20 outcome document as a reference to divide SD into 26 areas.

3. Year of official establishing SD offices/centers/institutes/network/committee: to determine the year that the universities officially began to work in the area of the SD.

The searches have been undertaken between September 2012 and January 2013 in the websites of the selected universities. The searches focused on internal search engines as well as on the website menus related to the sustainability projects/offices/centers/institutes. Moreover, the published reports have taken into consideration. These findings have been obtained by a group of volunteer students at the office of sustainability at AUT.

Each volunteer student surveyed two universities. The evidences have been rechecked for accuracy by two different students. At last, the ambiguous findings have been sent to the relevant universities (sustainability office, institute, center, group or committee) by email for corroboration. 4.3. Findings

After data collection, data processing operations consist of sorting, summarization, and aggregation were performed. Then, the obtained information has been conveyed into Table 2 .

Through an analysis of the information in Table 2, the following notes could be inferred:

All the studied universities have dedicated some parts of their activities to SD. These activities encompass various thematic areas. In fact, these could be considered as the reflection of a new attitude in these universities (passing over the first phase).

Since all of the studied universities have officially initiated their activities after 1990, it is concluded that some of the mentioned events, especially Rio (1992), could be a turning point in the relation between SD and HE, with a significant influence on the universities to extensively contribute in the field of SD (beginning of the second phase after 1990). Nevertheless, the role and the influence of the first period on the development of the second phase cannot be ignored.

Investigating the level and the scope of activities ${ }^{7}$ shows that during these years, the universities were seeking to implement and embed SD in different ways such as greening their campus, reducing their energy consumption, reducing their waste (implementing the second phase).

Some universities have even stepped into the third phase regarding their levels of activities, and they are seeking for meeting the needs embedded in their societies. For instance, there are research institutes in the universities that supply the demands of society and knowledge transferring from the universities to the society in area of SD.

Finally, the characteristics of these phases are aggregated and summarized in Fig. 6.

It is worth mentioning that these three phases are interrelated and dependent on each other, and each one is a necessary step for the coming one. Hence, as long as universities do not accomplish the first and the second phase, it is impossible to go through the third phase. In another word, universities have to accurately settle SD within themselves, and subsequently transfer it to the real world for making sustainable societies. ${ }^{8}$

\section{Future orientation of universities post Rio +20}

\subsection{The trends status under the influence of Rio +20}

In order to investigate the status of the trends and to identify the future orientation of universities following Rio +20 , an expert panel discussion was held at "the Sustainability and Higher Education Conference" at AUT in Tehran in December 2012. Six international experts or panelists presented their views about the topic. In this subsection, the integrated opinions and viewpoints of the panel experts are presented. 
Sustainability in top 20 universities.

\begin{tabular}{lrr}
\hline Rank University & $\begin{array}{r}\text { The level } \\
\text { activity }\end{array}$ & $\begin{array}{r}\text { The official } \\
\text { establishme }\end{array}$ \\
& &
\end{tabular}

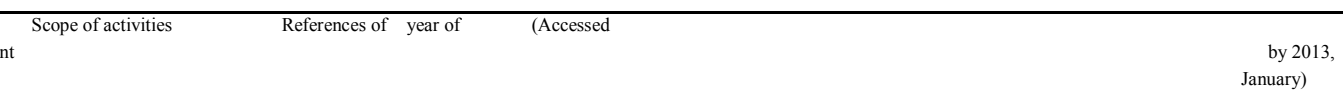

Climate Greenhouse Energy Green Waste \& Biodiversity Water Food Land Trans- Urban Environ- Others change gas management building recycling conservation portation sustain- 
UUUU

6 University

University of
Cambridge

7 MIT

$8 \quad$ Imperial College London

UU
Office, $\quad 1994$

Institute,

Networ

2008

(1)

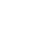

10 University of Berkeley

11 Yale University Office 2002

12 Columbia University Institute,

13 University of Institute, 2010 California, California,
Los Angeles

14 Johns Hopkins University

Center

Office, $\quad 2004$

Network

\section{1}

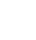

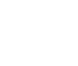


University College Institute London

University Office, of Michigan 2009 Institute

19 University f Toronto Office, 200

$20 \quad$ Cornel Office University u

u

บUบบ

u

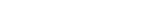

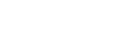

u u

uUU
O, P, Q, R University College London, Green Annual Report 2011/12, http://www.ucl.ac.uk/ greenucl/docs/ucl-es-annualreport-

H, N, R, S, T http://www.plantops.umichedu/

http://sustainability.umich.edu/ University of Michigan,

planet blue; Sustainability 2011 annual Report

http://www.ocs.umich.edu/pdf

Sustainability_AR2011.pdf

A University of Toronto, Sustainability

Office Report 2010,

http://sustainability utoronto.ca/ AssetFactory.aspx?vid=950;

http://www.sustainability.utoronto.ca/Page4.aspx

K $\quad$ http://www.sustainablecampus.cornell.edu/pages/ campussustainability-office

A.Beynaghietal./Futures63(2014)49-67

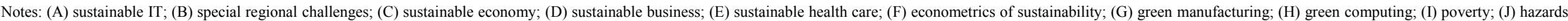

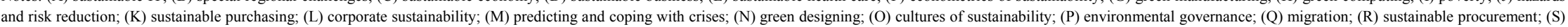
greening markets; (T) green technology 


\subsubsection{The trend of SD}

Study and survey of the SD trend showed that it has experienced three stages from 1972 to 2012. This trend originated from paying attention to human environment. The trend, however, started to expand step by step, and developed from a onedimensional to a multi-dimensional concept, which could comprehensively cover 26 different thematic areas in Rio +20 .

Nowadays, global challenges like global warming, climate change, population growth, resource constraints, water shortage, and poverty seriously threaten the human future and survival. Such threats are common global challenges which go beyond the national borders and call for a world-wide cooperation at an international level. Thus, considering a long-term approach, and the integration of different sets of knowledge to overcoming the threats are needed. Herein, an important question comes up that "what is this approach?"

According to the forty-year experience, the world community has accumulated in SD and specially at Rio +20 as an international event on SD, it is argued that the sustainability approach could be regarded as a reliable approach for saving the future. After Rio +20 , the world community will attempt to follow up the decisions of Rio +20 outcome at all levels, including global, regional, national, local, and community. As a result, it is expected that the SD trend will continue its evolution and step into a new phase, called "post sustainability". Some weak signals indicate that the SD concept is currently in transition from sustainability to this new phase. For example, publishing a book entitled "The Upcycle: Beyond SustainabilityDesigning for Abundance"' (McDonough \& Braungart, 2013) in April 2013 could be a sign associated with this evolution. In this phase, not only development but also every aspect of society should be sustainable.

\subsubsection{The trend of SD-HE}

The simultaneous study of SD and HE trends showed that there has been a nexus between SD and HE, so that it has gradually led to creation a new trend. Nowadays, this inextricable nexus has become a global trend (Leal Filho \& Manolas, 2012). As previously mentioned, the process of formation and evolution associated with this nexus was divided into three phases based on the universities that have achieved remarkable achievements in the area.

As stated by Leal Filho (2011b), several factors have been applied to help the reinforcement and expansion of this nexus during these years, some of which set in motion well before Rio +20 , which include many important documents (previously mentioned in Fig. 5). There have also been many groups working in this field, such as the COPERNICUS Alliance, the Association of Innovative Universities, the ad hoc sustainability Fora held at G8 events, the annual Davos Economic Conferences, or International Sustainable Campus Network, among many others. Even though over 600 universities worldwide have committed themselves toward sustainability by signing international agreements and conventions, and despite the fact that several thousand of them are pursuing matters related to SD on an ad hoc basis, many of them still struggle to put the principles of SD into practice due to a combination of reasons, varying from lack of institutional interest, to limited resources or staff involvement.

For instant, the United Nations has labeled the period between 2005 and 2014 as "UN Decade of Education for Sustainable Development (UNDESD)" and designated UNESCO ${ }^{9}$ to act as lead agency and follow the education programs in order to emphasize the critical role of education in achieving SD (Combes, 2005; Mula`\& Tilbury, 2009; Wals, 2014). In addition, as mentioned earlier, governments agreed upon 26 different areas to be supported for achieving a sustainable world in Rio +20 . One of these areas was dedicated to education. Different agreed viewpoints toward the education and its future are summarized in 7 paragraphs, as shown in Table 3. In fact, it could be asserted that such agreement can typically assist the facilitation and expansion of the SD-HE after Rio +20 .

Thus, it is expected to see more universities (compared to the time before Rio +20 ) showing the tendency for adopting the SD approach, and a more reinforced nexus between SD and HE.

\subsubsection{Possible interactive effects of the trends}

According to Miyazawa (2012), Rio +20 is a starting point for change. The important question is not how many treaties were signed or what specific actions were agreed on, rather, how and by what means such a change is possible? Taking the interactive effects between the trends of SD, $\mathrm{HE}$, and SD-HE, especially under the influence of Rio +20 , it is presented that the change is made by means of HE and universities. The reason is that HE and universities have always kept adapting themselves with the needs of societies, in order to improve the human living conditions (previously mentioned in the general trend of HE). Also, the inextricable forty-year nexus between HE and SD is a proof for the ability of HE to trigger the required changes (previously mentioned in the trend of SD-HE). Thus, it could be argued that HE and universities under the influence of SD are entering into a new period. In fact, Rio + 20 could be a starting point for change by HE and universities. "HE for SD" as an emerging new mission for universities, along with other missions, contributes to a sustainable world. As universities were the leaders in the space race and the war on cancer, they can potentially play a leadership role in this new era. Fig. 7 gives a description of the characteristics of this new period.

\section{2. "Sustainable university" post Rio +20}

As mentioned, in the new era, universities once again undergo a paradigm shift and performance changes. "HE for SD" is a new mission for universities, as pioneers in sustainability, having a leadership role in making a sustainable world. But, as 


\section{[(ig._6)TD\$FIG]}

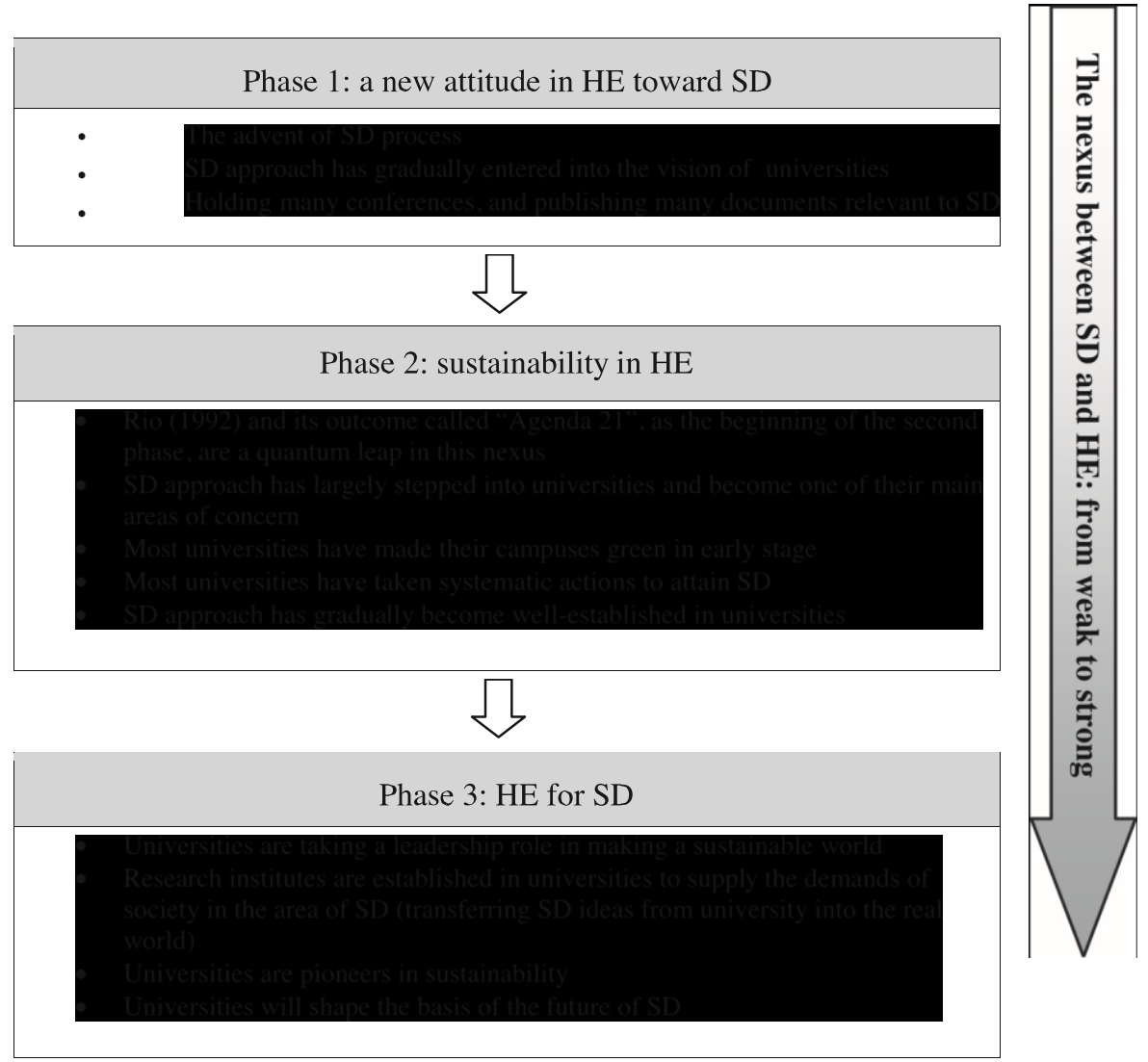

Fig. 6. The trend of SD-HE in the first, second and third phases, respectively.

Table 3

Different agreed viewpoints toward the education in "the Future We Want"' (The Future We Want, 2012).

1. Par 229 Access to all levels of education is essential for SD

2. Par 230 Development of curricula and programs for SD

3. Par 231 DESD goals must be used for ESD

4. Par 232 International cooperation, creation of fellowships and scholarships

5. Par 233 DESD should be continued after 2014

6. Par 234 Establishing offices for sustainability in universities to achieve sustainable campuses, sustainable courses and sustainable communities 7 . Par 235 Research and innovation for SD

Note: Education for Sustainable Development (ESD)

Mentioned in previous section, universities which have already passed the first and second phases are capable of perform this new mission. Therefore, it is expected that the concept of "sustainable university" will become more common in this era. In fact, although the term "sustainable university" was coined in the 1990‘s (Clugston \& Calder, 1999), it is merely feasible in third phase. This paper has analyzed the concept of "sustainable university" based on Rio +20 . Fig. 8 briefly describes how the concept of "sustainable university" could be divided into three categories:

As can be seen, the term "sustainable university" is conceptually equivalent to "university for SD". Moreover, it is obvious that SD has a multi-dimensional concept which requires concentration on 26 thematic areas to achieve a sustainable world, taking Rio +20 as a reference. These areas are divided into three interconnected categories using cluster analysis ${ }^{10}$ :

(1) Social well-being: the areas that lead to social sustainability.

(2) Environmental well-being: the areas that focus on environmental sustainability.

\footnotetext{
${ }^{10}$ The cluster analysis [by using Principal Component Analysis (PCA) method] was applied to the set of the most consistent areas, described by three parameters (pillars).
} 
(3) Economic well-being: the areas that result in economic sustainability in proportion with other aspects of SD.

Therefore, "sustainable university" could be divided into three interrelated and complementary groups parallel with the above-mentioned categories:

[(ig._7)TD\$FIG $]_{64}$

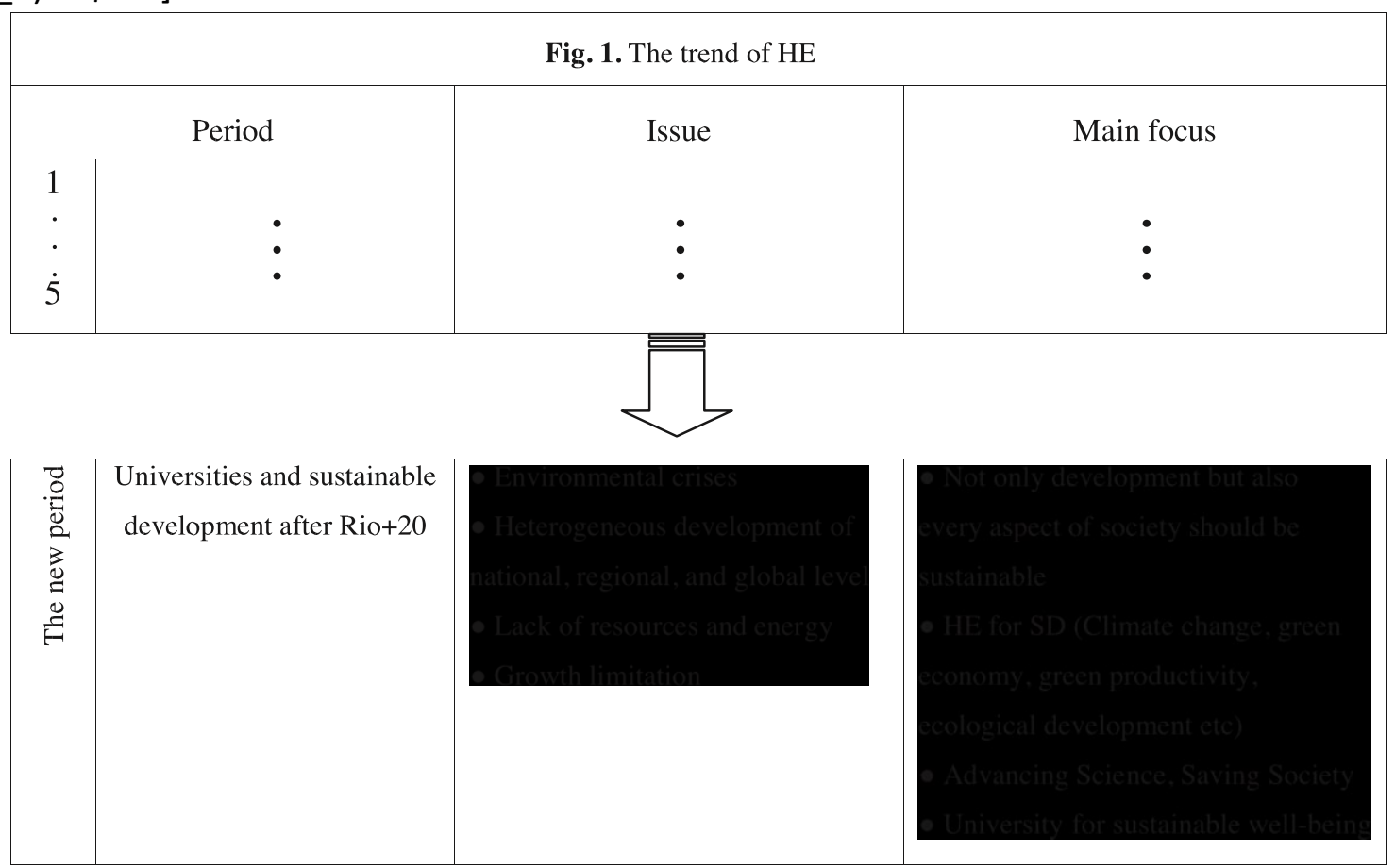

Fig. 7. The characteristics of the new period for $\mathrm{HE}$ and universities. 


\section{[(ig._8)TD\$FIG]}

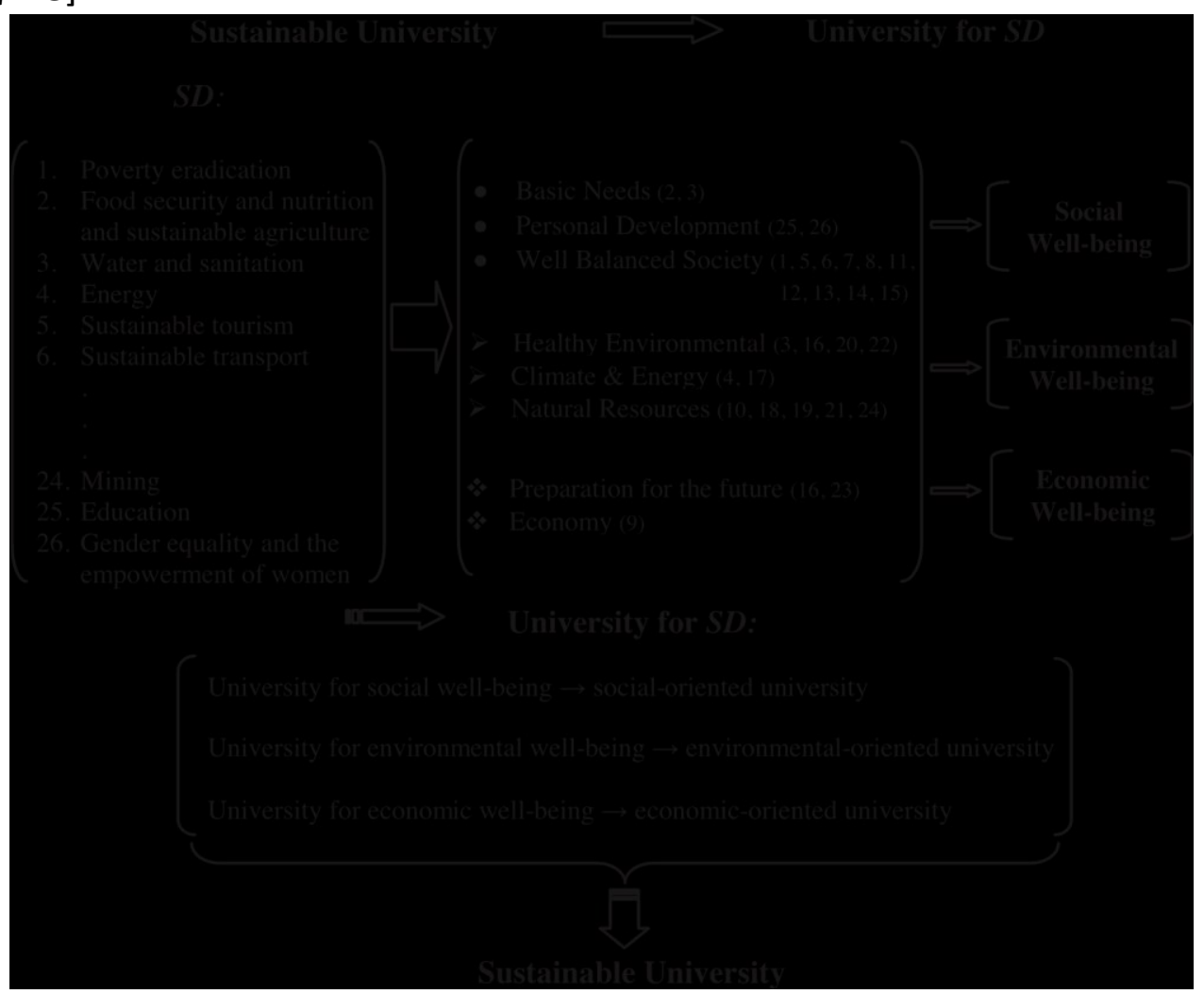

Fig. 8. "Sustainable university" following Rio +20 .

1. University for social well-being: social-oriented university

2. University for environmental well-being: environmental-oriented university

3. University for economic well-being: economic-oriented university

It is worth mentioning that universities specify their activities in certain areas which are selected according to their visions, missions, long-term goals, and social conditions. These areas are not necessarily related to only one of the mentioned groups, but also related to a combination of these groups. It is also obvious that these areas may vary from university to university. Different orientations, however, does not imply that universities have no responsibility to other areas.

In fact, "sustainable higher education" can build a sustainable future, when the total participants of HE (particularly universities) closely interact and make up a harmonic symphony. In other words, this is obvious that universities may take different orientations. These arrangements could vary based on different kind of macro-strategies for each country. Therefore, a country needs to find specific combinations and proportions under different circumstances. It is important to point out that one of the most common problems in the HE systems of developing countries is their inability to accurately determine their needs and effectively set up their arrangements. Moreover, as long as a society is not mature enough to accept the key role of universities in creating SD, it is impossible to complete this cycle. The missing factor of this cycle is the key role that a government plays in proper policymaking, legislation, preparation and making infra-structures, training within the society, and financial supports. In addition, some countries do not have the required capacity for entering into all areas of sustainability toward establishing a sustainable society due to many dramatic restrictions. Therefore, more international cooperation and interactions is extremely needed for achieving sustainable societies and ultimately a sustainable world.

\section{Conclusion}

This paper aimed to investigate the implications of SD for the future of $\mathrm{HE}$ and particularly universities through a global view. For this purpose, the selected approach was qualitative trend analysis so that three macro trends were combined as HE, SD and the nexus between SD and HE. The evaluation of how HE has been historically changed through a systematic approach showed that the universities had been always influenced by long-term environmental factors and experienced fundamental changes via five periods from elite to entrepreneurial universities. It has been shown that the trend of SD has been developed through a meaningful framework that runs from "human environment" to "environment and development" to "sustainable development". Analyzing the nexus between SD and HE eventually led to compiling three phases as "a new attitude in HE toward SD", "sustainability in HE", and "HE for SD". These phases showed that during the recent 40 years, this nexus has become more intertwined and turned into a bilateral relationship. 
Considering the interactive effects between the trends of SD, HE, and SD-HE, especially under the influence of Rio +20 , indicates that HE and universities are entering into a new era under the influence of SD. It is expected that "HE for SD", as a new mission for universities, can change the universities' performance toward a sustainable world in this new era. Therefore, the concept of "sustainable university" will become more common. According to the Rio + 20 outcome "The Future We Want", this concept has been divided into three interrelated categories (social, environmental, and economic oriented university). In such a way, the future orientation of each university can be in compliance with one or a combination of these categories.

\section{Acknowledgment}

I wish to express my appreciation to the following colleagues who provided comments on drafts of this paper: Bruce Tonn (University of Tennessee), Tarah Wright (Dalhousie University), Hyeonju Son (University of Hawaii at Manoa), Niko Roorda (Avans University), Tom Lombardo (Center for Future Consciousness), Daniella Tilbury (University of Gloucestershire), Marco Rieckmann (Leuphana University Lu"neburg), George Trencher (University of Tokyo). I would also like to thank an anonymous reviewer for helpful comments.

\section{References}

Association of European Universities (CRE) (1994). COPERNICUS - the university charter for sustainable development. Geneva, Switzerland: CRE-Copernicus Secrateriate. Atilla Oner, M., Basoglu, A. N., \& Kok, M. S. (2007). Megatrends as perceived in Turkey in comparison to Austria and Germany. Technological Forecasting and Social Change, $74,538-557$.

Atkins, D. E. (2005). University futures and new technologies: Possibilities and issues. In Unpublished discussion paper for an OECD expert meeting.

Azman, N., Sirat, M., \& Karim, M. A. (2010). Building future scenarios for Malaysian universities. Journal of Asian Public Policy, 3, 86-99.

Barth, M., Adom ent, M., Albrecht, P., Burandt, S., Godemann, J., Franz-Balsen, A., \& Rieckmann, M. (2011). Towards a sustainable university: Scenarios for sustainable university development. International Journal of Innovation and Sustainable Development, 5, 313-332.

Blass, E., Jasman, A., \& Shelley, S. (2010). Visioning 2035: The future of the higher education sector in the UK. Futures, 42, 445-453.

Boer, H., Huisman, J., Klemperer, A., Meulen, B., Neave, G., Theisens, H., \& Wende, M. (2002). Academia in the 21 st century: An analysis of trends and perspectives in higher education and research. In Adviesraad voor het Wetenschaps-en Technologiebeleid.

Bowen, G. A. (2009). Document analysis as a qualitative research method. Qualitative Research Journal, 9, 27-40.

Brinkhurst, M., Rose, P., Maurice, G., \& Ackerman, J. D. (2011). Achieving campus sustainability: Top-down, bottom-up, or neither? International Journal of Sustainability in Higher Education, 12, 338-354.

66

Brundtland, G. (1987). Our common future: Report of the 1987 World Commission on Environment and Development. Oxford: Oxford University Press.

Calder, W., \& Clugston, R. M. (2003). International efforts to promote higher education for sustainable development. Planning for Higher Education, 31, 30-44. Clugston, R. M., \& Calder, W. (1999). Critical dimensions of sustainability in higher education. Sustainability and University Life, 5, 31-46.

Cole, L., \& Wright, T. (2005). Assessing sustainability on Canadian University campuses: Development of a campus sustainability assessment framework. In W. Leal Filho (Ed.), Handbook of sustainability research (pp. 705-725). Frankfurt: Peter Lang.

Combes, B. P. (2005). The United Nations decade of education for sustainable development (2005-2014): Learning to live together sustainably. Applied Environmental Education and Communication, 4, 215-219.

Corcoran, P. B., \& Wals, A. E. (2004a). The problematics of sustainability in higher education: An introduction. In Higher education and the challenge of sustainability (pp. 3-6). New York, NY, United States: Springer.

Corcoran, P. B., \& Wals, A. E. (2004b). Higher education and the challenge of sustainability: Problematics, promise, and practice. Dordrecht: Kluwer Academic Publishers.

Cunha, M. M., \& Putnik, G. D. (2007). A changed economy with unchanged universities? A contribution to the university of the future. International Journal of Distance Education Technologies (IJDET), 5, 5-25.

Cutright, M. (2001). Chaos theory \& higher education: Leadership, planning, \& policy. Higher Education: Questions About the Purpose(s) of Colleges \& Universities, 9. (ISSN: 1523-9551).

Devos, A. (2003). Academic standards, internationalisation, and the discursive construction of "The International Student"'. Higher Education Research and Development, 22, 155166.

Dionne, J., \& Kean, T. (1997). Breaking the social contract: The fiscal crisis in higher education. New York: Report of the commission on national investment in higher education, council for aid to education.

DiSano, J. (1999). Sustainable development as a global trend. UN-FIG conference on land tenure and cadastral infrastructures for sustainable development.

Drexhage, J., \& Murphy, D. (2010). Sustainable development: From Brundtland to Rio 2012. Background paper for the high level panel on global sustainability.

Du Pisani, J. A. (2006). Sustainable development-historical roots of the concept. Environmental Sciences, 3, 83-96.

Duderstadt, J. J. (2012). The future of the university: A perspective from the Oort cloud. Social Research: An International Quarterly, 79, 579-600. ECI (2008). The earth

charter initiative - Handbook. San Jose', Costa Rica: Earth Charter International Secretariat.

EMSU 99: Environmental Management for Sustainable Universities, 30 May-1 June (1999). Lund, Sweden: Lund University.

Etzkowitz, H. (2004). The evolution of the entrepreneurial university. International Journal of Technology and Globalisation, 1, 64-77.

Etzkowitz, H., Webster, A., Gebhardt, C., \& Terra, B. R. C. (2000). The future of the university and the university of the future: Evolution of ivory tower to entrepreneurial paradigm. Research Policy, 29, 313-330.

Farasatkhah, M. (2009). University \& higher education, global perspectives and Iranian problems. Tehran, Iran: Nashr-e Ney.

GHESP (2003). Global higher education for sustainability partnership. http://webapps01.un.org/dsd/partnerships/public/partnerships/71.html.

Greenwood, M. (1995). In C. K. N. Patel (Ed.), Societal expectations from research universities and the higher education system, Reinventing the Research University (pp. 31-43). Los Angeles: Regents of the University of California.

Hashimshony, R., \& Haina, J. (2006). Designing the university of the future. Planning for Higher Education, $34,5$.

Hayes, T. (2007). Delphi study of the future of marketing of higher education. Journal of Business Research, 60, $927-931$.

Hens, L., \& Nath, B. (2003). The Johannesburg conference. Environment, Development and Sustainability, 5, 7-39.

Huisman, J., de Boer, H., \& Bo'tas, P. C. P. (2012). Where do we go from here? The future of english higher education. Higher Education Quarterly, 66, 341-362. IAU (2011).

World higher education database. Houndmills, Hampshire: Palgrave Macmillan.

International Institute for Sustainable Development, The Swansea Declaration, 2003, http://www.iisd.org/educate/declarat/swansea.htm.

International Institute for Sustainable Development, The Halifax Declaration, http://www.iisd.org/educate/declarat/halifax.htm Accessed 11.01.14.

IUCN, UNEP, \& WWF (1980). World conservation strategy - living resource conservation for sustainable development. Gland, Switzerland: International Union for Conservation of Nature and Natural Resources. 
Knight, W. E., Moore, M. E., \& Coperthwaite, C. A. (1999). Knowledge, skills, and effectiveness in institutional research (Vol. 1999, pp. 31-39). New Directions for Institutional Research.

Koroneos, C. J., \& Rokos, D. (2012). Sustainable and integrated development - a critical analysis. Sustainability, 4, 141-153.

Kreibich, R., Oertel, B., \& Wolk, M. (2011). Futures studies and future-oriented technology analysis principles, methodology and research questions. 1st Berlin symposium on internet and society.

Leal Filho, W. (2010a). Sustainability at universities: Opportunities. In Challenges and Trends. Frankfurt: Peter Lang.

Leal Filho, W. (2010b). Teaching sustainable development at university level: Current trends and future needs. Journal of Baltic Sea Education, 9, $273-284$.

Leal Filho, W. (2011a). Applied sustainable development: A way forward in promoting sustainable development in higher education. In W. Leal Filho (Ed.), World trends in education for sustainable development (pp. 11-29). Frankfurt: Peter Lang.

Leal Filho, W. (2011b). About the role of universities and their contribution to sustainable development. Higher Education Policy, 24, 427-438.

Leal Filho, w., \& Manolas, E. (2012). Making sustainable development in higher education a reality: Lessons learned from leading institutions. In GUNI higher education in the world 4: Higher education's commitment to sustainability from understanding to action (pp. 28-31).

Liebl, F., \& Schwarz, J. O. (2010). Normality of the future: Trend diagnosis for strategic foresight. Futures, 42, 313-327.

Lisa, N. (2007). The role of the United Nations: From Stockholm to Johannesburg. In Handbook of globalization and the environment. Boca Raton: CRC Press.

Lozano, R. (2006a). Incorporation and institutionalization of SD into universities: Breaking through barriers to change. Journal of Cleaner Production, $14,787-796$.

Lozano, R. (2006b). A tool for a Graphical Assessment of Sustainability in Universities (GASU). Journal of Cleaner Production, $14,963-972$.

McDonough, W., \& Braungart, M. (2013). The upcycle: Beyond sustainability - Designing for abundance. New York, NY, United States: North Point Press. Meadows, D. H.

(1972). Limits to growth: A report to the club of Rome. New York: Universe Books.

Mellow, G. O., \& Woolis, D. D. (2010). Teetering between eras: Higher education in a global, knowledge networked world. On the Horizon, 18, 308-319.

Miyazawa, I. (2012). What happened at Rio + 20? - lessons learned and the way forward, discussion paper Hayama, Japan: Institute for Global Environmental Strategies (IGES).

Mula', I., \& Tilbury, D. (2009). A United Nations decade of education for sustainable development (2005-2014) what difference will it make? Journal of Education for Sustainable Development, 3, 87-97.

Paul, B. D. (2008). A history of the concept of sustainable development: Literature review. The Annals of the University of Oradea: Economic Sciences Series, 17, 576- 580.

Peterson, M. W. (1999). The role of institutional research: From improvement to redesign (Vol. 1999, pp. 83-103). New Directions for Institutional Research.

Quental, N., Lourenc,o, J. M., \& da Silva, F. N. (2011). Sustainable development policy: Goals, targets and political cycles. Sustainable Development, 19 , 15-29.

Ritzen, J. (2006). Scenarios for higher education, 2020 or when will China invade Iran? Keynote address during the OECD ministerial meeting.

Ryan, A., Tilbury, D., Corcoran, P. B., Abe, O., \& Nomura, K. (2010). Sustainability in higher education in the Asia-Pacific: Developments, challenges, and prospects. International Journal of Sustainability in Higher Education, 11, 106-119.

Saritas, O., \& Smith, J. E. (2011). The big picture - trends, drivers, wild cards, discontinuities and weak signals. Futures, 43, $292-312$.

Seidel, P. (2011). To achieve sustainability. World Futures, 67, 11-29.

Stoddart, B. (2012). The politics of international education. http://www.globalpolicyjournal.com/blog/2024/2009/2012/politics-international-education.

The Future We Want, Outcome of the United Nations Conference on Sustainable Development, Rio de Janeiro, Brazil, 20-22 (June, 2012). http://www.uncsd2012.org/ thefuturewewant.html.

Trencher, G., Yarime, M., McCormick, K. B., Doll, C. N., \& Kraines, S. B. (2013). Beyond the third mission: Exploring the emerging university function of co-creation for sustainability. Science and Public Policy, sct044.

UN (2010). The millennium development goals report 2010. New York, NY, USA: United Nations.

UNEP (1972). Declaration of the United Nations Conference on the Human Environment, United Nations Environment Programme. http://www.unep.org/Documents.Multilingual/Default.asp?documentid1/497\&articleid1/41503 Accessed 10.01.14.

United Nations Education, Science and Cultural Organization (UNESCO), Lüneburg Declaration (2001). International COPERNICUS conference - higher education for sustainability - Towards the world summit on sustainable development (Rio + 10), Lüneburg, Germany.

United Nations Education, Science and Cultural Organization (UNESCO) (2009). The Bonn declaration. Bonn, Germany: UNESCO World Conference on Education for Sustainable Development.

Uni Graz, Oikos, COPERNICUS, \& TUG (2005). Graz declaration on committing universities to sustainable development. http://www-classic.uni-graz.at/geo2www/ Graz Declaration.pdf.

United Nations Conference on Sustainable Development (UNCSD), Rio de Janeiro, Brazil, 13-22 (June, 2012). http://www.uncsd2012.org/rio20/about.html .

United Nations Conference on Environment and Development (UNCED), Rio de Janeiro, 3-14 (June, 1992). http://www.un.org/geninfo/bp/enviro.html Accessed 08.02.13.

United Nations Education, Science and Cultural Organization (UNESCO) (1975). Belgrade, Serbia: Belgrade Charter.

United Nations Education, Science and Cultural Organization (UNESCO), Tbilisi Declaration, Georgia (1977).

United Nations Education, Science and Cultural Organization (UNESCO), Thessaloniki Declaration, Thessaloniki, Greece (1997).

University leaders for a sustainable future, Talloires Declaration (1990). Washington, DC, USA: ULSF.

University Summit Turino Declaration on Education and Research for Sustainable and Responsible Development, Turin Declaration (2009). Turino, Italy: G8 University Summit. van der Heijden, K. (2004). Afterword: Insights into foresight. In H. Tsoukas \& J. Shepherd (Eds.), Managing the future: Foresight in the knowledge economy (pp. 204- 211) Oxford: Blackwell.

Villez, K., \& Rengaswamy, R. (2013). A generative approach to qualitative trend analysis for batch process fault diagnosis. In IEEE European Control Conference (ECC) (pp. 19581963).

Vincent-Lancrin, S. (2004). Building futures scenarios for universities and higher education: An international approach. Policy Futures in Education, 2, 245-262. Vlasman, A., Quist, J., \& Mansvelt, J. V. (2004). Future visions and visioning for sustainability in higher education: Results and examples from The Netherlands. In D. Ferrer-Balas, K. F. Mulder, J. Bruno, \& R. Sans (Eds.), Proceedings of the second Engineering Education in Sustainable Development (EESD) conference (pp. 1-14). Volkwein, J. F. (1999). The four faces of institutional research (Vol. 1999, pp. 9-19). New Directions for Institutional Research.

Wals, A. E. J. (2014). Sustainability in higher education in the context of the UN DESD: A review of learning and institutionalization processes. Journal of Cleaner Production, 62, $8-15$.

Weisbrod, B. A., Ballou, J. P., \& Asch, E. D. (2008). An introduction to the higher education industry. In B. A. Weisbrod, J. P. Ballou, \& E. D. Asch (Eds.), Mission and money: Understanding the university (pp. 1-10). Cambridge: Cambridge University Press.

Wilkinson, A., \& Mangalagiu, D. (2012). Learning with futures to realise progress towards sustainability: The WBCSD Vision 2050 Initiative. Futures, $44,372-384$.

Wright, T. S. (2002). Definitions and frameworks for environmental sustainability in higher education. International Journal of Sustainability in Higher Education, 3, 203-220.

Zakaria, F. (May, 2009). The post-American world. New York, United States: W.W. Norton \& Company. 